ppi $201502 Z U 4645$

Esta publicación cientifica en formato digital es continuidad de la revista impresa ISSN-Versión Impresa 0798-1406 / ISSN-Versión on line 2542-3185Depósito legal pp

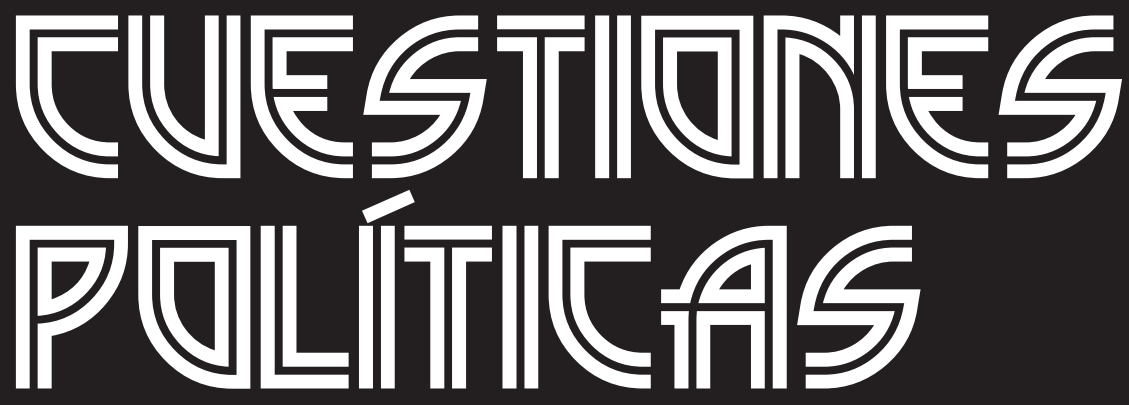

Instituto de Estudios Políticos y Derecho Público "Dr. Humberto J. La Roche' de la Facultad de Ciencias Jurídicas y Políticas de la Universidad del Zulia Maracaibo, Venezuela
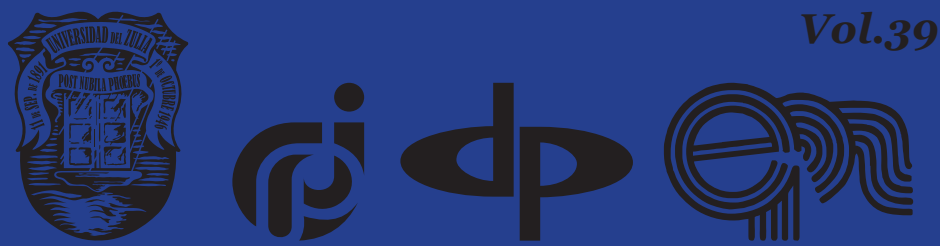


\title{
George W. Bush and the Political and Military Integration of the EU (2004-2008)
}

\author{
DOI: https://doi.org/10.46398/cuestpol.3968.14
}

\author{
Zakhar Vasilievich Pokudov * \\ Viktor Evgenievich Tumanin ** \\ Marat Zufarovich Galiullin *** \\ Elvira Imbelevna Kamaletdinova $* * * *$
}

\section{Abstract}

The aim of the article is to study European integration and the expansion of the European union together with the Atlantic alliance during George W. Bush's second term (2004-2008), for which the historical method was used. Despite the tendency that most researchers in the field of modern history and political science tend to focus on current events, and according to this logic it would be more appropriate to analyze Trump's foreign policy, in order to better understand the contemporary tension between the EU and the United States, today it is imperative to take a look at some contemporary historical processes. It is concluded that, to which George W. Bush's rhetoric has much in common with Donald Trump, he also laid the groundwork for change in U.S. foreign policy during Barack Obama's presidential term (2008-2016). The one-sided approach promoted primarily during George W. Bush's first term went from a gradual transformation of coalition building and the full support of the Atlantic alliance allies for the operation in Afghanistan in 2001, to more controversial rhetoric about "rebel states."

Keywords: International relations; regional studies-foreigners; contemporary political history; George Bush; European integration.

\footnotetext{
* Kazan (Volga Region) Federal University, Kazan, Russia. ORCID ID: https://orcid.org/oooo-ooo24282-7132. Email: zakharpokudov@gmail.com

** Kazan (Volga Region) Federal University, Kazan, Russia. ORCID ID: https://orcid.org/oooo-ooo29260-3217. Email: v.tumanin@mail.ru

*** Kazan (Volga Region) Federal University, Kazan, Russia. ORCID ID: https://orcid.org/oooo-ooo23798-4328. Email: maratscorpion@yandex.com

***** Kazan (Volga Region) Federal University, Kazan, Russia. ORCID ID: https://orcid.org/oooo-ooo33619-6335. Email: elvira-imoiv@mail.ru
} 


\section{George W. Bush y la integración política y militar de la UE (2004-2008).}

\section{Resumen}

El objetivo del artículo es estudiar la integración europea y la expansión de la unión europea junto a la alianza atlántica durante el segundo mandato de George W. Bush (2004-2008), para lo cual se hizo uso del método histórico. A pesar de la tendencia de que la mayoría de los investigadores en el campo de la historia moderna y la ciencia política tienden a concentrarse en los acontecimientos actuales, y según esta lógica sería más apropiado analizar la política exterior de Trump, para comprender mejor la tensión contemporánea entre la UE y los Estados Unidos, hoy en día es imprescindible echar un vistazo a algunos procesos históricos contemporáneos. Se concluye que, aunque la retórica de George W. Bush tiene mucho en común con Donald Trump, también sentó las bases para el cambio en la política exterior estadounidense durante el mandato presidencial de Barack Obama (2008-2016). El enfoque unilateral que se promovió principalmente durante el primer mandato de George W. Bush pasó por una transformación gradual de la creación de una coalición y la obtención del pleno apoyo de los aliados de la alianza atlántica para la operación en Afganistán en 2001, a una retórica más controvertida sobre los "estados rebeldes".

Palabras clave: Relaciones internacionales; estudios regionalesextranjeros; historia política contemporánea; George W. Bush; integración europea.

\section{Introduction}

The tension between the two flanks of NATO that has been growing throughout 2000-2002 skyrockets in 2003, which culminates in the Iraq war in 2003, in which France and Germany took strong opposition to the Anglo-American ideas of military actions in Iraq. Nevertheless, despite achieving its goal at the beginning of the operation, it quickly became evident that the Iraq's operation would be more complicated than it has been expected to be.

In such circumstances, the Bush's administration started to reconsider its point of view towards their European allies and seeking their support and strengthening the relationships by realizing that the unipolar world might be only an unrealizable utopia in the $21^{\text {st }}$ century. At the same time, while America was spending millions of dollars for its operation in Iraq and the neoconservative course of George W. Bush's administration became to be less popular, the EU became larger that unequivocally shifted the balance within the transatlantic union towards Brussels. 


\section{Zakhar Vasilievich Pokudov, Viktor Evgenievich Tumanin, Marat Zufarovich Galiullin y Elvira Imbelevna Kamaletdinova \\ 236 \\ George W. Bush and the Political and Military Integration of the EU (2004-2008)}

Thus, George Bush started to change his unilateral policy towards a more cooperative one. However, his neoconservative course, which was based mostly on the ides of Realpolitik, was persistent until the end of his presidency, that was only highlighted by the dispute about Membership Action Plan for Georgia and Ukraine in 2008, and future Russian-Georgian conflict which also pointed out the boundaries for the expansion of both NATO and EU and laid down the basis for the Barack Obama's European policy.

\section{Methods}

The leading method to research this problem is the historical and systematic method allowing understanding the laws of the European integration, trace the consistent patterns and regularities of military cooperation between the EU and the US. The historical and genetic method helps in creating the factual framework for the analysis and to identify how the issues of the European integration are connected with the military cooperation within the Transatlantic alliance and to understand better what legacy Barack Obama will inherit from the administration of the 43rd American president.

\section{Results and Discussions}

The Iraq War, which began in March 2003, divided the European Union into two camps. The first camp that was led by France and Germany strongly opposed the war. The second camp with such countries as the UK, Spain, and Italy, supported American actions. The Iraq War led to a few more contradictions between the EU and the US even before the beginning of the military conflict, and the alliance with its forces was divided. For instance, in January 2003 Germany, France, and Belgium refused to provide security guarantees for Turkey if the last would have been attacked by Iraq. According to Serfaty, Iraq was a mistake for Europe long before it became to be a mistake for the U.S., because it highlighted the lack of common ground within the European part of the alliance and we can gradually trace it: in 2002 European countries were scared that they were unable to stop the war in Iraq, in 2003 because they did not form a solid position concerning the military operation, in 2004 because they were playing only a secondary and auxiliary role in the liberation of Iraq they were not able to influence the process of its reformation, which was mostly done by the US (Serfaty, 2005). Thus, the Iraq war highlighted the military disbalance between two flanks of the transatlantic union and the unilateral moment of the USA. However, despite this inability to find a shared position in terms of foreign politics, the European integration went further. 
The enlargement of the European Union on 1 May 2004. This enlargement was not only the biggest one for the European Union in terms of the number of countries (10 new countries were added), but also in terms of the population because it added 74 million people to the population of the EU, which overall number became 455 million. Candidate countries were gradually fulfilling acquis communautaire (Ispolinov, 2010), legislation and legal acts that might put the legal system of candidate countries on par with the same system of old members, and on May 1, 2004, the Czech Republic, Hungary, Estonia, Latvia, Lithuania, Slovenia, Slovakia, Poland, Malta, and Cyprus officially joined the European Union, previously introducing approximately 50000 new laws. After their admission to the European Union those countries continue reforms by creating new financial and legal institutions. Nevertheless, most of these countries were not ready to introduce euros. For instance, Slovenia, Malta, and Cyprus introduced euro in 2007, while Slovakia did the same only in 2009. Further expansion of the eurozone had been paused due to the financial crisis of 2008-2009 (Tibor, 2010).

Due to a significant economic disbalance between the countries of Western Europe and countries of Eastern Europe, we shall take into account political motivation for this. For instance, even in the most economically developed country from these 10 Eastern European countries - Slovenia, GDP per capita was only 68\% from an average number of the European Union. The share of the service sector in GDP that is commonly considered to be an essential measure while talking about postindustrial economics which among old members of the EU was around 67\% in the Czech Republic was only 53,7\%, and in Romania, which joined the EU in 2007 it was even less $-41,7 \%$. Moreover, a share of agriculture in the GDPs of the Eastern European members was much higher in comparison to Western Europe (Batorshina, 2011). Thus, despite enforcing acquis communautaire (European Commission, 2019) Eastern European countries still supposed to walk a long road on the way to the economic standards of the western flank of the EU.

To support the new legal foundation for a much bigger union, the European Constitution was created in October 2004. Despite the only legal procedures, this constitution also had a symbolic meaning - the European flag, anthem, and motto were adopted. Furthermore, talking about European political institutions, a typical "governmental" terminology was used. For instance, European law, the European minister of foreign affairs etc. It should have influenced a collective European identity among various European nations. According to Levina, "The constitution recalled for governments and citizens that the European Union is not only a common market but also a system of political governance, which is based on the common values and principles" (2010: 58). Nevertheless, despite the creation of such a Constitution, it had not been adopted, and the next 
legal action which would enforce political ideas of this constitution would be the Lisbon Treaty, which was signed in December 2007 and enacted on 1 December 2009 (Levina, 2010).

The next European enlargement happened in 2007, when Romania and Bulgaria joined the European Union, even though it was evident that these countries were not ready to join the European Union. According to Tibor, the European Union had never before integrated countries with such a low average income, which was 3,500 and 4,500 dollars in Bulgaria and Romania respectively. The comparison to the 9,200 dollars of average income for the ten previously admitted Eastern and Central European countries, and especially to the 29000 dollars income among average countries in the European Union, was striking. Moreover, Bulgaria and Romania had problems with corruption and transparency and had a lousy infrastructure (Tibor, 2010). Nevertheless, with the enlargement of the European Union the Schengen area had also enlarged. Thus, in December 2007 Poland, the Czech Republic, Slovakia, Slovenia, Hungary, Malta, Lithuania, Latvia, and Estonia joined the Schengen area. In December 2008 Switzerland joined, which in the same manner as Norway and Iceland, is a member of the Schengen area, but not a member of the European Union (Dragunova, 2008).

Nonetheless, we might also say that during the first decade of the 21st century, Europe was enlarging not only to the East but also to the West. Despite some political conundrum between the USA and the EU, the trade between these two political entities remained to be extremely lucrative. To point out this fact, in 2007 the transatlantic economic integration act was signed between the president of the European Commission, José Manuel Barroso, George W. Bush and Angela Merkel (Nolan, 2012). Therefore, the future of the transatlantic relationships looked bright. For instance, that is how José Manuel Barroso commented on the transatlantic relationships before signing this treaty, "Our political relationship with the US is as close as ever, based on deep ties of kinship. With the international role of the US economy as powerful as ever and with the EU now firmly back on the growth and jobs path, this is the right time to deepen our economic partnership and to further strengthen the transatlantic economy. This agreement will allow us to demolish existing, unnecessary barriers posed by divergent regulations and nip new ones in the bud. With the necessary political commitment and follow up on all sides, the new framework will deliver lower costs for businesses and consumers on both sides of the Atlantic» (European Commission, 2007).

Moreover, with the economic cooperation, the military cooperation was also striving. Western Europe in 2007 held a solid second place among world regions in terms of military spending, by spending 301 billion dollars, which was $22,5 \%$ from the world military spending. In addition to 
it, Central and Eastern Europe also considerably increased their military spending - by $162 \%$ in 2007 , which was the biggest increase in military spending among world regions, thus considerably contributing to the European forces. Nonetheless, despite big numbers, European military was still strongly lagging behind the American military because European forces were consisting of 27 different forces that still needed some coordination, which might be extremely complex in terms of communication and at least a universal language.

Additionally, among the member states, these spending's were also unequal. For instance, while Spain was spending in 2007 12,3 billion dollars, the UK spent 59,2 billion dollars. Furthermore, as it had already been shown with the example of the Iraq War, it was extremely complex to find a common political agenda for the various members of the European Union. For instance, the 2008 Kosovo declaration of independence vividly demonstrated it. This declaration was supported by France, the UK, Germany, Italy, and 46 other countries around the globe. Nonetheless, Spain, Greece, Cyprus, Romania, Bulgaria, Slovakia, and other 100 countries, which had problems with ethnic minorities, refused to admit the existence of Kosovo, and Miguel Ángel Moratinos, who was a minister of foreign affairs of Spain, even called it "a violation of international law" (Tibor, 2010: 28).

Nevertheless, Bush's administration was eager to encourage Europeans to spend more on their defense. Bush's administration also had an economic reason for it - by the beginning of his second term due to the "costly war on terror" the 200 billion dollars surplus which George W. Bush inherited from Clinton's administration, was turned into a 400 billion dollars of annual deficit (Rielly, 2008).

Furthermore, in 2008 a new era in relationships between NATO and the Russian Federation had begun with NATO plans for further expansion to the East, and American plans of placing missile defense systems in Poland and the Czech Republic, and military conflict in Georgia. After the end of the Cold War, NATO had considerably expended and after incorporating Latvia, Lithuania, and Estonia was situated on the Russian western borders, which immediately swung geopolitical balance in favor of the Western alliance.

This fact was somehow unpleasant for the Russian political establishment, (Beloglazov et al., 2019) and military conflict in Georgia in 2008, clearly showed boundaries for a further western military (NATO) and political expansion (EU). Furthermore, the issue concerning further NATO extension had separated western allies even before. For instance, during the NATO's summit in Bucharest 2-4 April 2008 George W. Bush was pushing to accelerate the participation of Georgia and Ukraine in Membership Action Plan (MAP), which is considered to be the first step before being fully integrated in the transatlantic alliance. However, 
Germany and France decisively blocked this intension by referring to the internal political instability and "frozen conflicts" in South Ossetia and Abkhazia (Noetzel and Schreer, 2009). As the historian of the European Union Martin J. Dedman pointed out, the U.S. and its western allies must have been finally decided how to perceive post-Soviet Russia - as an ally in a fight against global terrorism, or as a geopolitical competitor that should be contained. To perceive Russia from both sides was impossible, which the military conflict in Georgia vividly emphasized (Dedman, 2010).

\section{Conclusion}

Therefore, despite all the setbacks of the first Bush's presidency in the euro-American relationships, during the second Bush's term these relationships improved. Nevertheless, as pointed by a professor of international relations at Georgetown University Charles A. Kupchan "Certainly we are not back to where we were during the pre-Bush era, but we also have climbed back from the abyss in relations that surrounded the Iraq war" (Bush Second Term Repairs Damage to European Relations, 2008). Despite the fact that the European integration went further, and the EU became bigger, the Russian-Georgian conflict of 2008 underlined the limits of possible expansion to the East for both NATO and EU.

To sum up, in this article, military cooperation between the EU and the United States during two presidential terms of George W. Bush has been analyzed. At the dawn of the $21^{\text {st }}$ century the relationships between the USA and EU were developing due to potential economic competition, for instance in terms of steel, and some misunderstandings in terms of foreign policies. However, after September 11 attacks, NATO was unified against a common enemy - international terrorism. However, the Iraq War proved to be divisive for the Western alliance and highlighted difficulties of the European Union in terms of finding a common position. Moreover, American foreign policy and especially the Bush Doctrine, which was based on a significantly increased American military and economic might, highlighted the existing imbalance between the two flanks of the transatlantic alliance. However, it did not stop the European integration, with the 5th and the 6th enlargements in 2004 and 2007 respectively. 2008 became to be a quite divisive year for the European foreign policy again with Kosovo declaration of independence and military conflict in Georgia. The last also pointed out possible boundaries for the NATO and EU expansion to the East of the Union. In terms of military, in the end of the Bush's second term the strong economic ties between the European Union and the United States remained to be present, as well as a significant military imbalance between these two political entities, despite the fact that Europe became much bigger in terms of population and active military personnel. 


\section{Acknowledgments}

The work is performed according to the Russian Government Program of Competitive Growth of Kazan Federal University.

\section{Bibliographic References}

BATORSHINA, Irina Alexandrovna. 2011. "The fifth wave of the European enlargement: pro et contra" In: Baltic region. No. 3, pp. 49-58 (in Russian).

BELOGLAZOV, Albert Vladislavovich; MUBARAKSHINA, Anastasiya Mikhailovna; ZAKIROV, Almaz Vasilovich. 2019. "Global Supply Chain Strategy in the Cooperation of Russia and Tajikistan in the Field of Security in the Early 21st Century" In: International Journal of Supply Chain Management (IJSCM). Vol. 8, No. 5, pp. 943-947.

DEDMAN, Martin. 2010. The origins and development of the European Union: 1945 - 2008; a history of European integration. Routledge. Edinburgh, Scotland.

DRAGUNOVA, Evgeniya V. 2008. "Processes of the European integration in the second of the 2oth century: unity and diversity" In: Herald of the Leningrad State University. 143-154. (in Russian).

EUROPEAN COMMISSION. 2007. "EU and US to sign up to transatlantic economic integration plan at Washington Summit on 30 April" In: European Union: European Commision. Available online. In: https:// europa.eu/rapid/press-release_IP-07-587_en.htm. Consultation date: 13/12/2019.

EUROPEAN COMMISSION. 2019. European Neighbourhood Policy and Enlargement Negotiations. Available online. In: https://ec.europa.eu/ neighbourhood-enlargement/policy/conditions-membership/chaptersof-the-acquis_en. Consultation date: 20/11/2019.

ISPOLINOV, Alexei. 2010. "The concept of acquis Communautaire in law of the European Union" In: Moscow University Herald. No. 5, pp. 68-87 (in Russian).

LEVINA, Natalia. 2010. "Lisbon Treaty - the new basic document of the European Union” In: Herald of People's Friendship University of Russia. Section: law, pp. 98-104 (in Russian).

NOETZEL, Timo; SCHREER, Benjamin. 2009. "Does a Multi-Tier NATO Matter? The Atlantic Alliance and the Process of Strategic Change" In: International Affairs. Vol. 85, No. 2. pp. 211-226. 
Zakhar Vasilievich Pokudov, Viktor Evgenievich Tumanin, Marat Zufarovich Galiullin y Elvira Imbelevna Kamaletdinova

242 George W. Bush and the Political and Military Integration of the EU (2004-2008)

NOLAN, Mary. 2012. The Transatlantic Century: Europe and America, 18902010. Cambridge University Press. Cambridge, England.

RIELLY, James T. 2008. “The Bush's Administration's Foreign Policy Legacy” In: Politique américaine. No. 12, pp. 73-86.

SERFATY, Simon. 2005. The vital partnership: power and order: America and Europe beyond Iraq. Rowman \& Littlefield. Michigan, USA.

TIBOR, Balogh. 2010. Europe Since 1980. Cambridge University Press. Cambridge, England. 
ISSN 0798-1406 Depósito legal pp 198502ZU132

\section{Cuestiones Políticas}

\section{Planilla de suscripción}

Nombre

Institución

Dirección

Ciudad País

Cheque de gerencia a nombre de: Universidad del Zulia (LUZ),

Facultad de Ciencias Jurídicas y Políticas, Ingresos Propios

Banco Occidental de Descuento, Cuenta corriente № 212700890-9

Tarifa de suscripción por un año (dos números):

Venezuela: Bs. 80 + Envío

Ejemplar solo: Bs. $40+$ Envío

América Latina \$ $40+$ Envío

Resto del mundo $\$ 50+$ Envío

Esta planilla debe ser enviada a la siguiente dirección:

Revista "Cuestiones Políticas"

Facultad de Ciencias Jurídicas y Políticas

Instituto de Estudios Políticos y Derecho Público

Apartado Postal 526, Maracaibo Venezuela

Puede adelantar información por: cuestionespoliticas@gmail.com

loichirinosportillo@gmail.com 